\title{
Astaxanthin-Producing Microalgae Identification Using 18S rRNA : Isolates from Bangkalan Mangrove Waters and Sowan Tuban Northern Waters, East Java, Indonesia
}

\author{
Dini Ermavitalini'*, Siska Yulia Rukhmana ${ }^{2}$, Thalita Meidina ${ }^{2}$, Leonardo Pascalis Dimas Cahyo \\ Baskoro $^{2}$, Triono Bagus Saputro', Ni'matuzahroh ${ }^{3}$, Hery Purnobasuki ${ }^{3}$ \\ 1)Department of Biology , Faculty of Science and Data Analytics, Institut Teknologi Sepuluh Nopember. Kampus ITS Keputih \\ Sukolilo Surabaya 60111, East Java, Indonesia \\ 2)Alumni of Department of Biology, Faculty of Science and Data Analitycs, Institut Teknologi Sepuluh Nopember. Kampus ITS \\ Keputih Sukolilo Surabaya 60111, East Java, Indonesia \\ 3)Departement of Biology, Faculty of Science and Technology, Universitas Airlangga. Kampus C, Jl. Mulyorejo Surabaya 60115, \\ East Java, Indonesia \\ * Corresponding author, email: diniermavitalini80@gmail.com
}

Submitted: 24 March 2021; Accepted: 07 August 2021; Published online: 04 October 2021

\begin{abstract}
Microalgae are a group of micro-sized photosynthetic organisms that range from prokaryotic cyanobacteria to eukaryotic algae. Microalgae are widely used as a source of natural food, cosmetic ingredients, food ingredients, and a source of pigments. This study aims to identify species of four microalgae isolates named B1, B2, B3, and S2 from Bangkalan Mangrove Waters and Sowan Tuban Northern Waters, and to determine their astaxanthin pigment concentration under $1 \mathrm{M} \mathrm{NaCl}$. Species identification was carried out through a molecular approach by utilization of an $18 \mathrm{~S}$ rRNA gene marker. A quantitative test of astaxanthin concentration was carried out by spectrophotometric analysis. Molecular identification results show that isolates B1 and B3 are closely related to Cblorella sp., while isolates B2 and S2 are closely related to Picochlorum maculatum. Moreover, under salinity stress condition of $1 \mathrm{M} \mathrm{NaCl}$ shown a significant decrement of astaxanthin production compared to the control treatment. At $1 \mathrm{M} \mathrm{NaCl}$, the astaxanthin content of isolate $\mathrm{B} 1$ was $4 \times 10^{-5} \mathrm{mgL}^{-1}$, isolate $\mathrm{B} 2$ was $2 \times 10^{-}$ ${ }^{5} \mathrm{mgL}^{-1}$, isolate B3 was $1 \times 10^{-5} \mathrm{mgL}^{-1}$, and isolate $\mathrm{S} 2$ was $6 \times 10^{-6} \mathrm{mgL}^{-1}$. All in all, isolate $\mathrm{S} 2$ has the highest astaxanthin among the other isolates at normal conditions, while under salt stress regime, isolate B1 shown to be the best source for astaxanthin.
\end{abstract}

Keywords: Astaxanthin, Bangkalan Mangrove Waters, Chlorella sp., Picocblorum maculatum Sowan Tuban Northern Waters

\section{INTRODUCTION}

Microalgae are plant-like protists commonly referred to as phytoplankton with a diameter of between 3-30 $\mu \mathrm{m}$, single-celled or in simple colonies. The microalgae group is a large group that varies from prokaryotic cyanobacteria to eukaryotic algae scattered in many phyla. Microalgae are single-celled 
organisms with simple structures that have the ability to convert carbon dioxide and water using solar energy into biomass. Microalgae can be found widely in various types of waters and are capable of multiplying their biomass rapidly during exponential times (Yanuhar 2016). Meanwhile, according to Guiry (2012), there is still uncertainty about what characteristics cause an organism to be classified as an algae and its taxonomic hierarchy. However, until June 2012 there were 44,000 algal species names that have been published with a conservative identification approach. This is the cause of the importance of having the ability to science algae systematics. Referring to Suparman (2012) identification using morphological data is an identification that is often used but this method is less effective because of a long time and often the appearance of the morphology of organisms is influenced by external factors so that the results of the identification obtained are not consistent. The shortcomings of this method have led to the identification and analysis of the relationship between organisms. Methods in identifying organisms have developed from the use of morphological identification up to the use of molecular identification based on some pieces of short DNA called "DNA barcode" (Hebert et al. 2003; Zulfahmi 2013). DNA Barcode refers to the use of standard short DNA regions to identify organisms even if the DNA is incomplete, damaged, or degraded (Hajibabaei et al. 2007). 18S rRNA gene is a common molecular marker for biodiversity studies because it is highly conserved within a single species (close to 100\% similarity) and helps in species-level analyses.

Microalgae produce pigments that are focused on three types, namely chlorophyll, phycobillin, and carotenoids (Elfiza et al. 2019). Carotenoids are natural pigments produced in fungi, bacteria, algae, and plants but are not produced by animals. Carotenoids are used as ingredients in vitamin supplements, cosmetics, health food products, and addictive substances. Carotenoids that have been studied include $\beta$-carotene, lutein, lycopene, zeaxanthin, and astaxanthin (Coates et al. 2013). Astaxanthin with the structural formula 3,3'-dihydroxy- $\beta$, $\beta$-carotene-4,4'-dione is a ketocarotenoid that is synthesized in limited quantities in microalgae, plants, bacteria, and fungi. Unlike primary carotenoids (e.g., $\beta$-carotene, zeaxanthin, and lutein) which are components of the photosynthetic apparatus, which is in charge of collecting light energy and transferring energy to chlorophyll in photosynthesis (Demmig-Adams et al. 1996) astaxanthin is a secondary carotenoid that accumulates in cells when the cells are subjected to environmental stress or adverse culture conditions, such as high light, high salinity and nutritional deficiencies (Han et al. 2013). Salinity stress in the form of high salt concentrations in the medium will cause disruption of the osmotic balance and $\mathrm{Na}+$ poisoning resulting in a decrease in the microalgal cell growth rate. Under conditions of salinity stress, microalgal cells will make physical and biochemical adjustments such as inhibition of photosynthesis, synthesis of macromolecular compounds, and adjustment of homeostasis. (Wang et al. 2018). Environmental stress causes Reactive Oxygen Species (ROS) in cells that cause damage to DNA, proteins, and cell membranes. ROS at the same time stimulate the emergence of secondary carotenoids such as astaxanthin which consume molecular oxygen during ROS synthesis so that it will directly reduce the formation of ROS (Collins et al. 2011). Environmental stress conditions will cause the accumulation of secondary carotenoids such as astaxanthin and ketolutein and result in the degradation of chlorophyll pigments and primary carotenoids (Mulders et al. 2015). The ratio value of the carotenoid pigments concentration to chlorophyll pigments concentration becomes an indicator of carotenogenesis in microalgae cells which will increase when microalgae cells are exposed to environmental 
stress conditions due to the accumulation of secondary carotenoids (Chen et al. 2017).

Astaxanthin has been reported to have the most potent antioxidant activity compared to other carotenoids (Han et al. 2013). Astaxanthin antioxidant activity is the ability to capture reactive oxygen species (ROS) and neutralize free radicals in the cells because astaxanthin has thirteen conjugated double bonds arranged as single double bonds. Astaxanthin is widely used in nutraceuticals and pharmaceuticals for diseases associated with increased free radicals such as cancer, cardiovascular disease, degenerative diseases of the eye. Astaxanthin is also a common coloring agent in aquaculture to provide red pigmentation (Lorenz \& Cysewski 2000; Guerin et al. 2003).

Some of the microalgae that produce astaxanthin in their cells, among others Botryococcus braunii which is equal to $0.01 \%$ astaxanthin by dry weight, Haematococcus pluvialis which is equal to $4 \%$ astaxanthin by dry weight, Eremosphera viridis, and Trachelomonas volvocina (Han et al. 2013), Chlamydocapsa $s p$. which is equal to $0.04 \%$ astaxanthin by dry weight (Leya et al. 2009), Chloromonas nivalis which is equal to $0.004 \%$ astaxanthin by dry weight (Remias et al. 2010), Chlorella zofingiensis which is equal to $0.7 \%$ astaxanthin by dry weight Neochloris wimmeri which is equal to $1.9 \%$ astaxanthin by dry weight, Protosiphon botryoides which is equal to $1.4 \%$ astaxanthin by dry weight, Scotiellopsis oocystiformis which is equal to $1.1 \%$ astaxanthin by dry weight (Orosa et al. 2000), Chlorococcum sp. which is equal to $0.7 \%$ astaxanthin by dry weight (Ma \& Chen 2001), Scenedesmus obliquns which is equal to $0.3 \%$ astaxanthin by dry weight (Qin et al. 2008).

Indonesia is an archipelago with 17,508 islands, and a coastline of $81,290 \mathrm{~km}$, which is united by a sea of 5.8 million $\mathrm{km}^{2}$. However, the development of the marine and fisheries sector is still far from expectations, even though Indonesia's coastal and marine areas have enormous potential natural resources and have not been optimally utilized (Lasabuda 2013). Mangrove ecosystems are known as brackish forest ecosystems because they are found in water areas with salinity levels between $0.5 \%$ oo and $30 \%$ oo. This ecosystem is also known as a tidal forest ecosystem because it is found in areas that are affected by tides (Noor et al. 1999). Microalgae that live in brackish and marine ecosystems have the ability to adapt to living in saline environments. This research aims to explore and identify the species of microalgae from both mangrove waters located in Sepulu sub-district, Bangkalan Madura and the northern waters of Sowan, Tuban, East Java and then tested the concentration of astaxanthin produced by microalgae isolates after experiencing salinity stress. Based on a review of the literature, exploration of microlagae of Indonesia's local resources in Bangkalan mangrove waters and the northern waters of Sowan, Tuban East Java as a producer of astaxanthin has not been widely carried out until this article was compiled. In this study, microalgae that were isolated from both locations were induced to produce astaxanthin in vitro in high saline medium of $1 \mathrm{M}$ or equal to $83 \%$ as a salinity stress.

\section{MATERIALS AND METHODS}

\section{Microalgae sampling}

The sampling of microalgae was carried out in December 2019 in mangrove waters, Sepulu sub district, Bangkalan Madura and in the northern waters of Sowan, Tuban, East Java. A sampling of microalgae was performed by the horizontally towing method, namely plankton net size $0.08 \mathrm{~mm}$ drawn horizontally by boat at a constant speed $(10 \mathrm{~km} /$ hour$)$ for a certain distance at a water depth of $0-50 \mathrm{~cm}$. A sampling of microalgae in the northern waters 


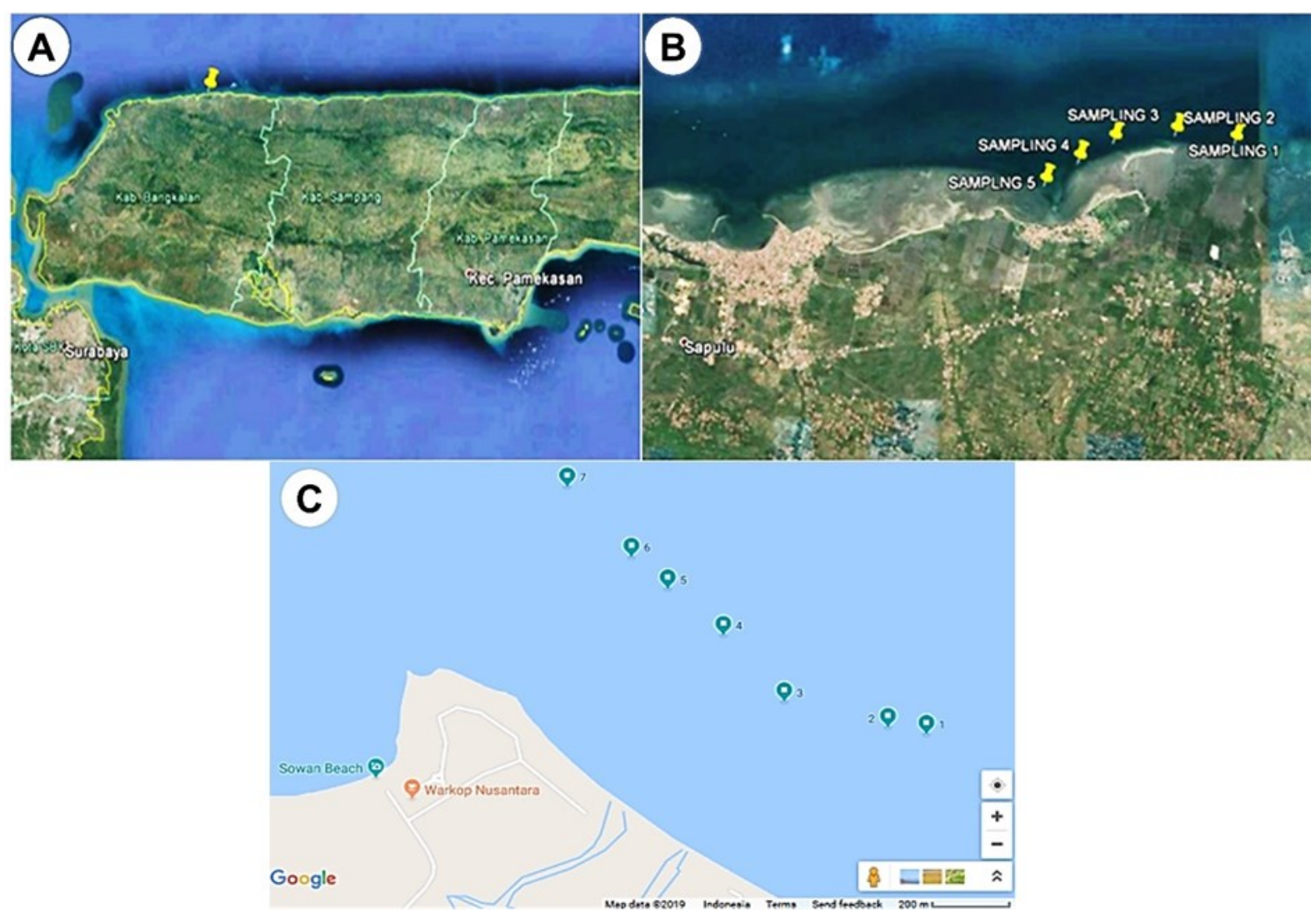

Figure 1. A) Sampling location seen from the north of Madura Island $\left(6^{\circ} 52^{\prime} 48^{\prime \prime} \mathrm{S} ; 113^{\circ} 0^{\prime} 7^{\prime \prime} \mathrm{T}\right)$ and B) sampling locations in the Bangkalan mangrove waters Madura, East Java with 5 sampling points. C) Sampling locations in the northern waters of Sowan Tuban, East Java with 7 sampling points.

of Sowan, Tuban was carried out at a distance of \pm 500 meters from the coastline through seagrass and coral vegetation. Sampling was done by using a motorboat with a speed of $10 \mathrm{~km} /$ hour with a distance between stations along the 200 meters. Samples of microalgae from all stations were collected in one sampling bottle and then stored in a cooler box (Sulardiono et al. 2015). The sampling points in Bangkalan mangrove waters and northern waters of Sowan Tuban show in Figure 1.

\section{Identification of microalgae isolates}

Isolation, purification, and cultivation of microalgae

Isolation, purification, and cultivation were carried out at the Laboratory of Plant Bioscience and Technology, Department of Biology, Faculty of Science and Data Analysis, Sepuluh Nopember Institute of Technology. The medium used was f / 2 Guillard liquid medium for dilution and f / 2 Guillard solid medium for the streak plate method. Making liquid media was done by filtering seawater, respectively from the mangrove waters of Bangkalan Madura and northern waters of Sowan Tuban. The water from the sampling site was used as a solvent for Guillard f / 2 media. In making f/2 solid media, $10 \mathrm{~g} / \mathrm{L}(1 \%)$ agarose was added to the liquid medium (Thao et al. 2017). The microalgae samples were diluted using stratified dilution method in sterile $\mathrm{f} / 2$ Guillard liquid medium. The stratified dilutions were carried out aseptically and obtained $10^{-2}, 10^{-3}$, and $10^{-4}$ dilutions. A total of 5 drops of sample from each level of dilution were placed onto the surface of the sterile solid medium and leveled using drygalski (cell spreader). Isolates were incubated at room temperature $\left(23-25^{\circ} \mathrm{C}\right)$ with 24 : 0 light: dark photoperiod for 7-14 days (Azzahidah \& Ermavitalini 2016). The isolate colonies that grew on the medium were transferred to a new sterile solid medium using the streak plate method. The selection of isolates was based on colony 
morphology, colony color, and differences in cell morphology. The process was carried out continuously until pure isolates were obtained. Monoculture isolates were transferred gradually to liquid media. The ratio of isolates and media is $1: 10$. Cultivation is carried out by giving aeration everyday at room temperature $\left(23-25^{\circ} \mathrm{C}\right)$, with a light: dark photoperiod $24: 0$ for 14 days (Azzahidah \& Ermavitalini 2016).

\section{Genome DNA Extraction and determination of the concentration}

The extraction of DNA genome using Genomic DNA Mini Kit (Plant) GeneaidTM following the protocol from the manufacture. Determination of DNA concentration using a nanodrop spectrophotometer using a ratio of $260 \mathrm{~nm} / 280 \mathrm{~nm}$. The purity value was obtained from the absorbance ratio at a wavelength of $260 \mathrm{~nm}$ which is absorbed by DNA with absorbance at a wavelength of $280 \mathrm{~nm}$ which is absorbed by the contaminants. Genome DNA was then treated with RNase to eliminate RNA and subjected to electrophoresis by using $0.8 \%$ of agarose gel in $0.5 x$ TBE (Tris-Borat-EDTA) buffer.

Primers Design, PCR amplification, electroporation, and Gene Sequencing In this research, the primers pair were designed at the new position and not using the universal primers. The DNA sequence of several $18 \mathrm{~S}$ rRNA genes for green microalgae named Chlorella sp. (AB176665.1), Haematococcus lacustris (LT578169.1), Chlamydomonas orbicularis (AB511839.1), Golenkinia sp.

(AF499924.1), Mychonastes sp. (AB727554.1) were retrieved from the NCBI database (www.ncbi.nlm.nih.gov). The sequence was then subjected to the MultAlin online software (http://multalin.toulouse.inra.fr/multalin/) for alignment purposes. The primers pair were chosen at the conserved region manually to customize the expected products. Neb calculator was used to calculating the melting temperature for each oligonucleotide sequence. The primer homodimer, heterodimer, and secondary structure were analyzed using the online software OligoAnalyzer (https://sg.idtdna.com/calc/ analyzer). From the process, we obtain forward primer: 5'-CGATGGTAGG ATAGAGGCC-3', while the reverse primer is: 5'-CTAGGCATTCCTCGT'T GAAG-3'.

The genome obtained during the extraction process was used as a template for the DNA amplification process. DNA amplification begins with the mixing of the primary reagents forward, reverse, $\mathrm{ddH}_{2} \mathrm{O}$, DNA template, and kit. DNA Amplification uses a PCR BIOER GeneTouch Thermal cycler and was carried out by setting the temperature and time according to the GoTaq Green Master Mix protocol. The steps of DNA polymerization with a PCR machine are carried out as follows: predenaturation step is set on $94^{\circ} \mathrm{C}$ for 30 seconds and done in 1 cycle, denaturation step is set on $94^{\circ} \mathrm{C}$ for 30 sec and done in 40 cycles, annealing step is set on $50^{\circ} \mathrm{C}$ for $30 \mathrm{sec}$ and done in 40 cycles, elongation step is set on $72^{\circ} \mathrm{C}$ for 30 seconds and done in 40 cycles. PCR products were observed using electrophoresis. Moreover, $2 \%$ of agarose in $0.5 x$ TBE buffer was used to visualize the DNA genome and PCR products. Electroporation processes were conducted at 100 volts for $35 \mathrm{~min}$. DNA fragments were observed with a UV transilluminator. The correct size of the PCR product was then purified and subsequently sequenced using Sanger Method.

The Content of chlorophyll, carotenoids, and astaxanthin test Preparation of microalgae culture and cultivation medium The microalgae that were isolated from both sampling locations as a single colony and pure culture on solid medium were obtained from method 2.2.1, then cultured in liquid medium. microalgae isolated from the northern waters 
of Sowan Tuban, East Java. The medium used for microalgae culture is seawater obtained from commercial providers. Seawater is filtered with a filter membrane, then the salinity is measured at 30-32 ppt (Endrawati et al. 2013) then added Walne fertilizer.

\section{Determination of starter time and harvest time}

Determination of harvesting time was carried out by making a culture of 500 $\mathrm{ml}$ with $10 \%$ by volume of pure microalgae culture. Microalgae cultures B1, B2, B3, and S2 were measured every 24 hours until they reached the death phase using a UV-Vis spectrophotometer at a wavelength of $680 \mathrm{~nm}$. The starter period is a half exponential period of culture. Determination of harvest time is done by making growth curves of B1, B2, B3, and S2 microalgae cultures that were given stress treatment. The salinity treatment was carried out by giving $\mathrm{NaCl}$ with a concentration of $1 \mathrm{M}$. Culture growth was measured every 24 hours until it reached the death phase using a UV-Vis spectrophotometer at a wavelength of $680 \mathrm{~nm}$. The statistical phase is defined as the harvest time for the culture.

\section{Quantitative analysis of chlorophyll and carotenoids}

A total of $4 \mathrm{ml}$ of sample was taken and centrifuged at $3000 \mathrm{rpm}$ for $10 \mathrm{~min}$ or $4000 \mathrm{rpm}$ for $5 \mathrm{~min}$. The supernatant was removed and the cells were put in $4 \mathrm{ml}$ of distilled water to remove the salts in the biomass, then centrifuged. Washing in distilled water was carried out twice. The sample was suspended in $4 \mathrm{ml}$ of ethanol solvent, then centrifuged for $10 \mathrm{~min}$ at a speed of 3000 rpm (Henriquez et al. 2007). The supernatant was taken to measure its absorbance using a spectrophotometer. The absorbance was measured at a wavelength ( $\lambda$ ) $645 \mathrm{~nm}$ for chlorophyll b analysis, ( $\lambda$ ) $662 \mathrm{~nm}$ for chlorophyll an analysis, ( $\lambda$ ) $470 \mathrm{~nm}$ for carotenoid analysis. The blank used was $96 \%$ ethanol as a comparison (Pratama \& Laily 2015). The amount of pigment is calculated based on the Lichtenthaler (1987) formula shown in Table 1. (Zawislak \& Wierdak 2014).

Table 1. The formula for calculating the concentration of chlorophyll a, chlorophyll $\mathrm{b}$, and carotenoids.

\begin{tabular}{ll}
\hline $\mathrm{C}_{\mathrm{a}}$ & $11,75 \mathrm{~A}_{662}-2,350 \mathrm{~A}_{645}$ \\
$\mathrm{C}_{\mathrm{b}}$ & $18,61 \mathrm{~A}_{645}-3,960 \mathrm{~A}_{662}$ \\
$\mathrm{C}_{\mathrm{x}+\mathrm{c}}$ & $1000 \mathrm{~A}_{470}-2,270 \mathrm{C}_{\mathrm{a}}-81,4 \mathrm{C}_{\mathrm{b}} / 227$ \\
\hline $\mathrm{C}_{\mathrm{a}}=$ chlorophyll $\mathrm{a}, \mathrm{C}_{\mathrm{b}}=$ chlorophyll $\mathrm{b}, \mathrm{C}_{\mathrm{x}+\mathrm{c}}=$ total carotenoids \\
\hline
\end{tabular}

\section{Quantitative analysis of astaxanthin}

A total of $10 \mathrm{ml}$ of sample was taken and centrifuged at $7000 \mathrm{rpm}$ for $5 \mathrm{~min}$. The pellets were taken and then added $5 \mathrm{ml}$ of $5 \% \mathrm{KOH}$ in $30 \%$ methanol at a $75^{\circ} \mathrm{C}$ water bath for $10 \mathrm{~min}$ to remove chlorophyll. The remaining pellets were added $25 \mu \mathrm{l}$ of acetic acid at $75^{\circ} \mathrm{C}$ for $10 \mathrm{~min}$. The pellets were extracted using DMSO. At this stage, it is repeated several times until the colour sample fades. The pigment is measured using a spectrophotometer with a wavelength $(\lambda)=492 \mathrm{~nm}\left({ }^{E_{1 \varepsilon m}^{196}}\right)=2220$ and can be calculated by the formula (Li et al. 2019):

$$
\begin{aligned}
& \mathrm{CA}(\mathrm{mg} . \mathrm{L}-1)=\left(\mathrm{A} 492 \times 1000 / E_{1 \epsilon m}^{196} \times 100\right) \times \mathrm{Va}(\mathrm{mL}) / 10(\mathrm{Ml}) \times \mathrm{f} \\
& \mathrm{CA} \quad: \text { Concentration of astaxanthin; } \\
& \mathrm{Va} \quad \text { : Volume of extract; } \\
& \mathrm{f} \quad \text { dilution rate }
\end{aligned}
$$




\begin{abstract}
Data Analysis
The DNA sequences resulting from the sequencing were combined between reverse and forward primers using BioEdit software. Furthermore, the sequences that have been obtained were analyzed using the alignment contained in the Nucleotide Basic Local Alignment Search Tool (BLASTn) on the NCBI portal. Furthermore, phylogenetic trees were created using MEGA 7.0 software (Saputro et al. 2019). Phylogenetic trees were constructed using Neighbour-joining with bootstrap 1000 times. Meanwhile, quantitative data on chlorophyll, carotenoid, and astaxanthin concentrations were presented as the average of three repeated measurements. Data analysis was carried out by quantitative descriptive by comparing stress treatment with control without stress treatment.
\end{abstract}

\title{
RESULTS AND DISCUSSION
}

\section{Results}

The results of microalgae isolation from mangrove waters located in Sepulu sub-district Bangkalan and northern waters of Sowan Tuban, East Java, obtained 4 isolates that can be cultivated as pure culture in liquid media, namely isolates B1, B2, B3, and S2. Figure 2 below is the result of microscopic observations of the four isolates of microalgae under a microscope (Optilab Viewer) and microalgae isolate B1, B2, B3 and S2 in liquid culture.
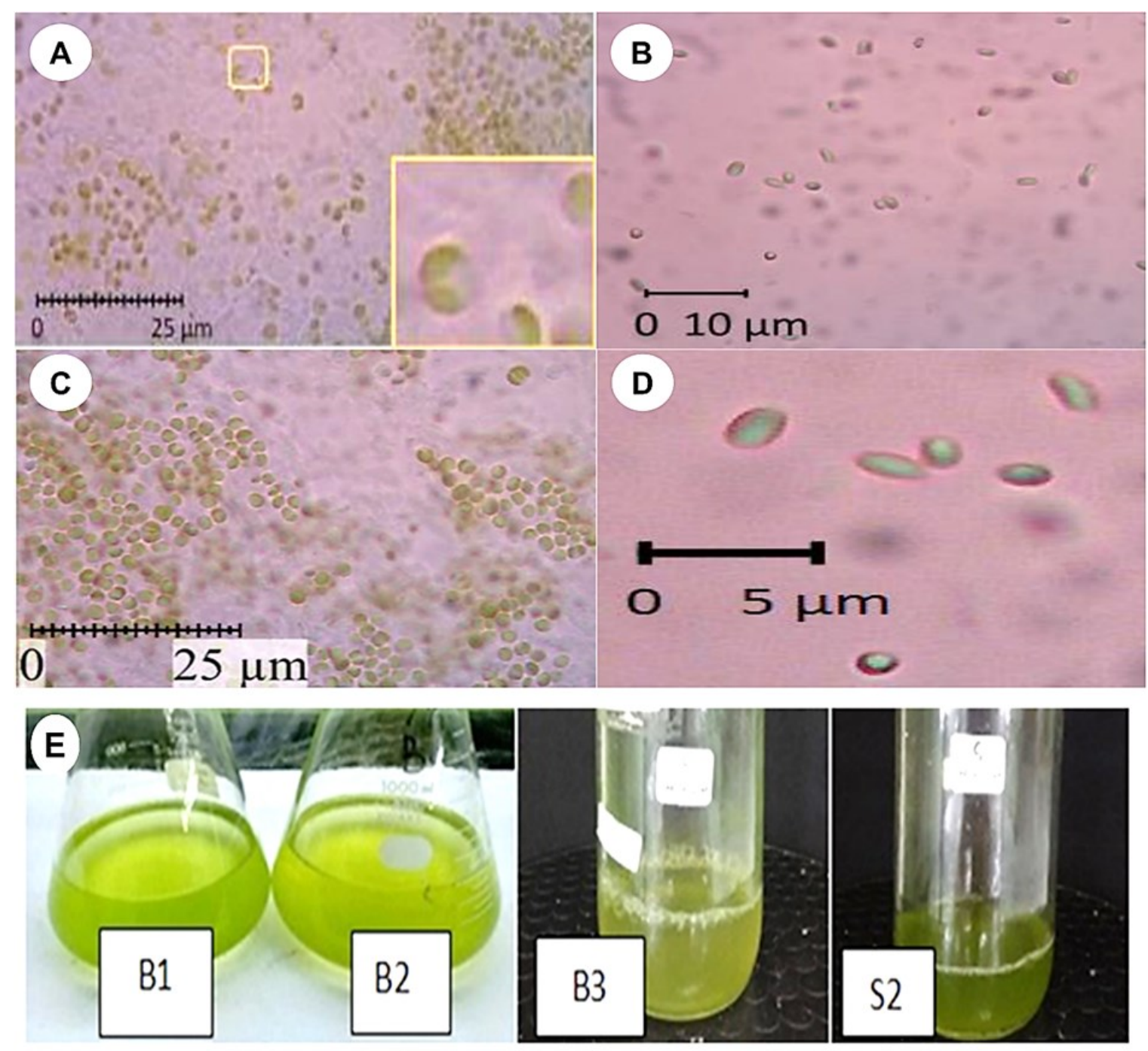

Figure 2. A). Microalgae cells isolate B1, B). Microalgae cells isolate B2, C). Microalgae cells isolate B3. D). Microalgae cells isolate S2, E). Microalgae isolate B1, B2, B3, and S2 in liquid culture. 
The molecular identification stage of microalgae isolates using the $18 \mathrm{~S}$ rRNA marker gene began by measuring the purity of the isolated DNA using a nanodrop spectrophotometer ND-1000 with a wavelength of $260 \mathrm{~nm}$ and $280 \mathrm{~nm}$. The measurement results show that the purity value is in the range 1.97-2.13 and the concentration value is in the range of $14-24.3 \mathrm{ng} / \mu \mathrm{L}$. These results indicate that the purity of the DNA sample and the DNA concentration have met the requirements as a template in the amplification process on the PCR machine (Sambrook et al. 1989). Purity with a value of 1.8-2.0 is the feasible value of the microalgae genome sample to go to the DNA amplification process and electrophoresis stages (Mustafa et al. 2016). The value of DNA purity affects the success of amplification because, with a good purity value, the DNA bands formed will be clearly visible on visualization under UV light. The following is the result of visualization of DNA bands on electrophoretic gel under UV light and Table of Differentiation rich among the samples and retrieved 18S rRNA (Figure 3).

The four isolates that have been identified then tested for the concentration of chlorophyll, carotenoid and astaxanthin pigments at salinity conditions with a concentration of $1 \mathrm{M} \mathrm{NaCl}$. Testing the concentration of the pigment chlorophyll, carotenoids and astaxanthin can describe carotenoids in microalgae cells under stress, where microalgae cells under stress will accumulate secondary carotenoids including astaxanthin and reduce the concentration of chlorophyll pigments and primary carotenoids. (Chen et al. 2017).

Based on Figure 5A it can be seen that isolates B1, B2, B3, and S2 entered an adaptation phase (lag phase) on $1^{\text {st }}$ day, then entered the logarithmic phase starting on $1^{\text {st }}$ day to $12^{\text {th }}$ day. The four isolates entered different stationary phases wherein isolate B1 and isolate B3 the stationary phase started from $12^{\text {th }}$ day to $14^{\text {th }}$ day, while isolates B2 and S2 started from $12^{\text {th }}$ day to $13^{\text {th }}$ day. The death phase of isolates B1 and B3 started on $14^{\text {th }}$ day, while for isolates B2 and S2 the death phase started on $13^{\text {th }}$ day. This is in accordance with the results of molecular identification which show that

(B)

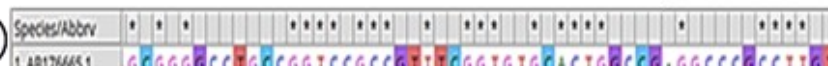

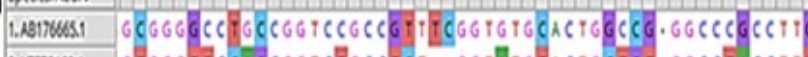

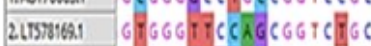

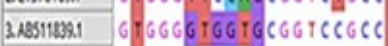
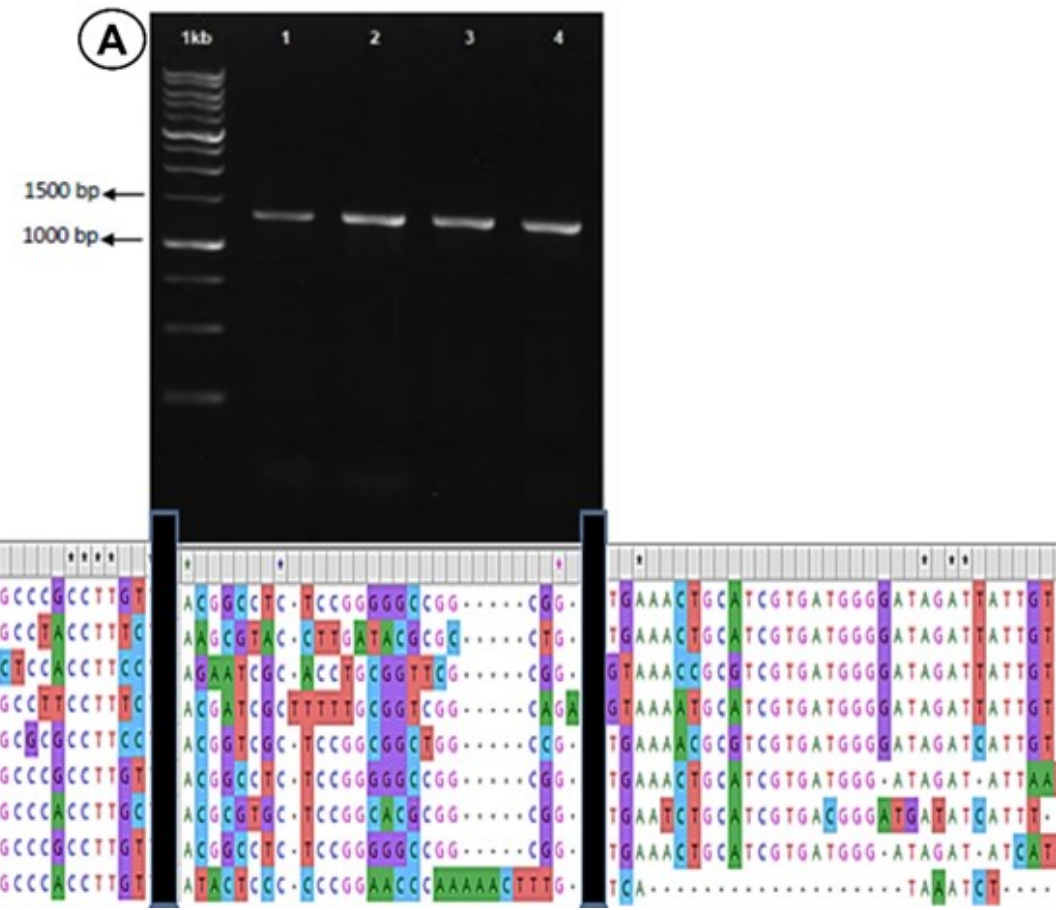

Figure 3. A) Visualization of electrophoretic DNA bands under UV light (1 is DNA band of microalgae isolate B1, 2 is DNA band of microalgae isolate B2, 3 is DNA band of microalgae isolate B3 and 4 is DNA band of microalgae isolate S2); B) The area has shown differentiation rich among the samples and retrieved $18 \mathrm{~S}$ rRNA. 


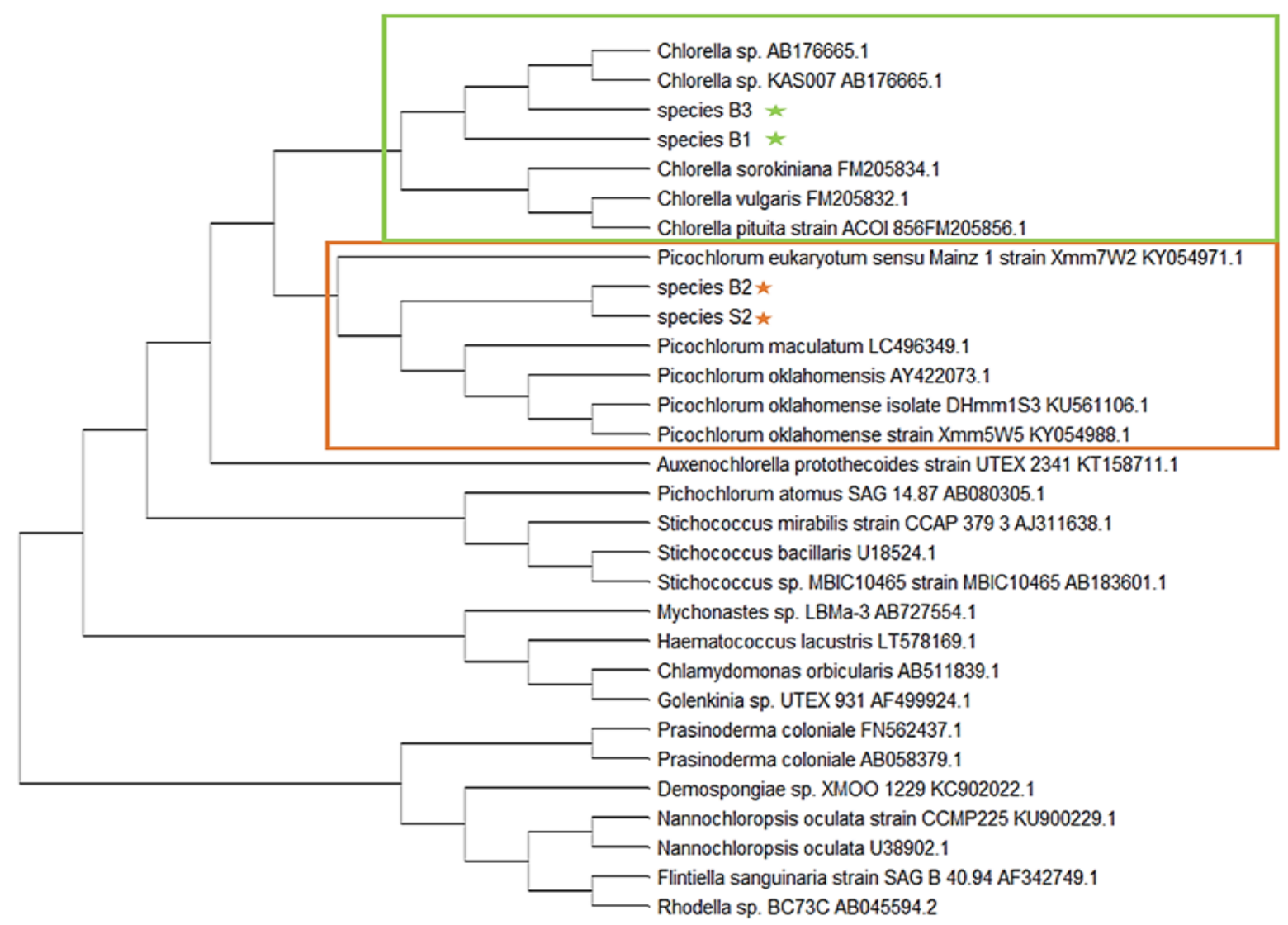

Figure 4. Phylogenetic tree construction based on the 18S-rRNA gene using the Neighbour Joining Tree bootstrap 1000x method.

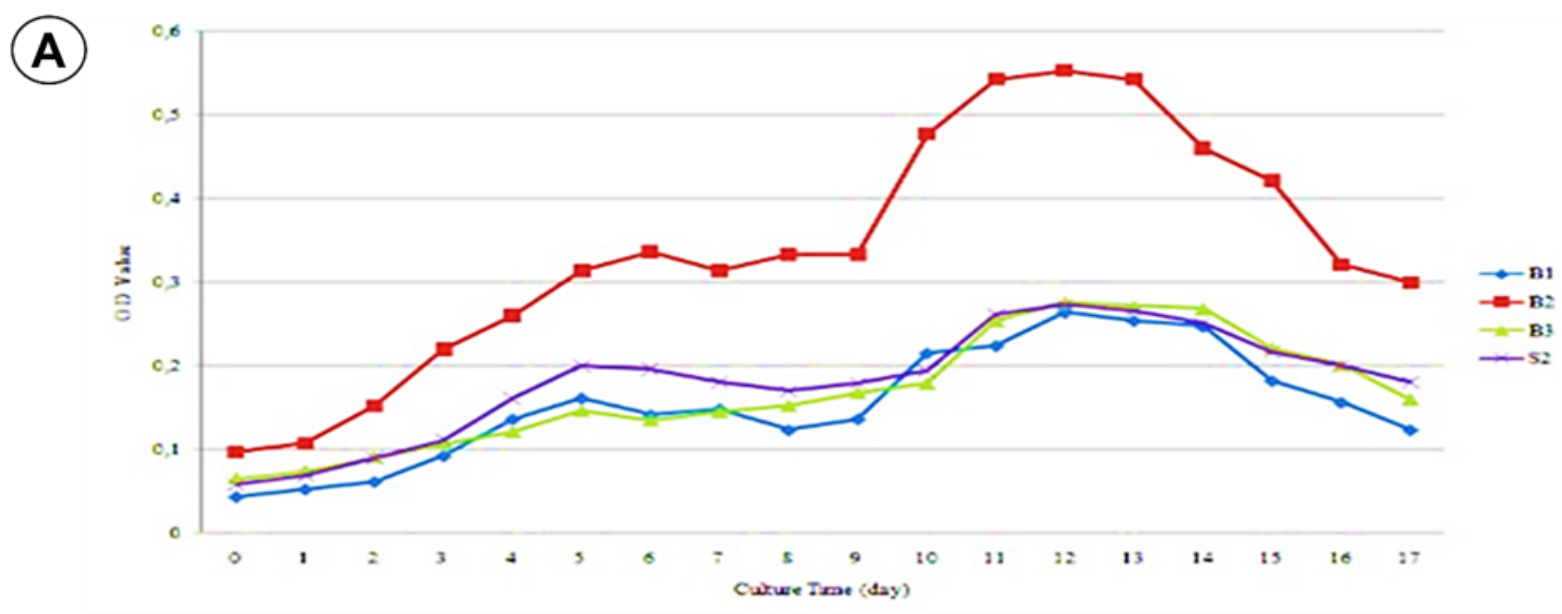

(B)

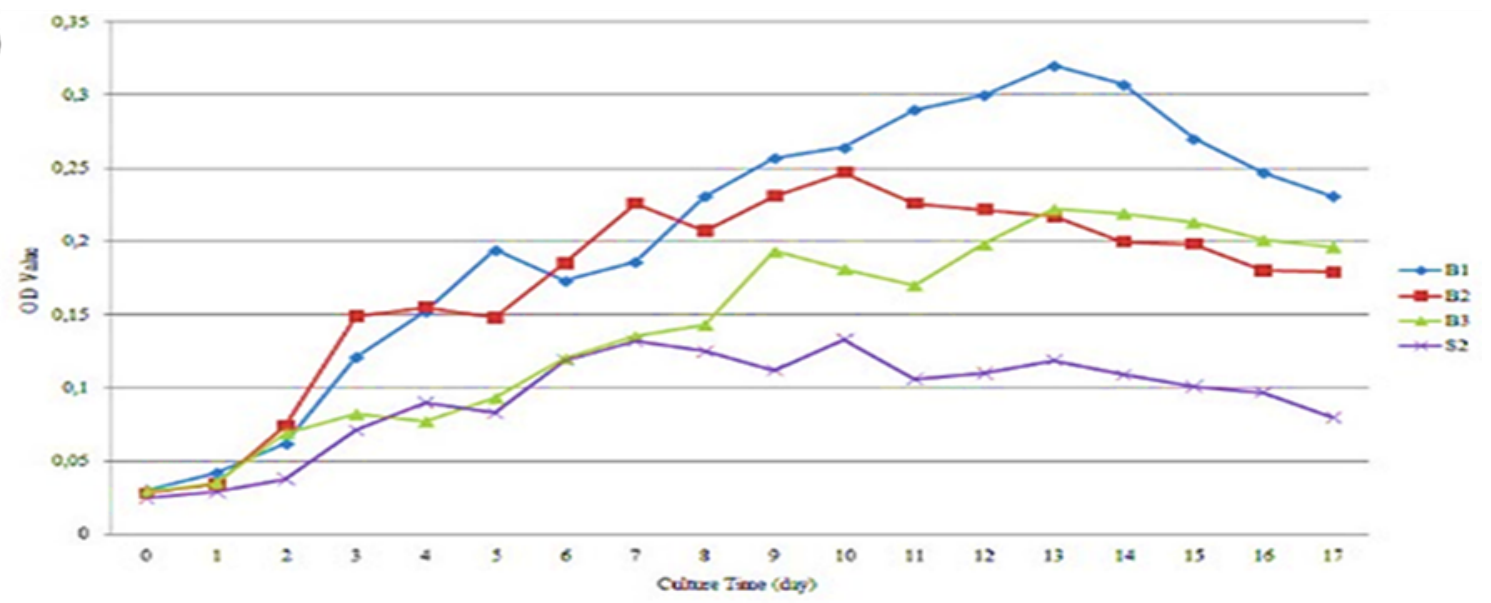

Figure 5. A). Growth curves of isolates B1, B2, B3, and S2 under normal conditions; B). Growth curves of isolates B1, $\mathrm{B} 2, \mathrm{~B} 3$, and $\mathrm{S} 2$ under a salinity stress condition of $1 \mathrm{M} \mathrm{NaCl}$ 
Table 2. Chlorophyll, carotenoid, and astaxanthin concentrations in isolates B1, B2, B3, and S2 under 1 M salinity stress conditions.

\begin{tabular}{|c|c|c|c|c|}
\hline Isolates Name & Treatment & $\begin{array}{l}\text { Chlorophyll } \\
\text { Concentration } \\
\left(\mathrm{mgL}^{-1}\right)\end{array}$ & $\begin{array}{c}\text { Carotenoid } \\
\text { Concentration } \\
\left(\mathrm{mgL}^{-1}\right)\end{array}$ & $\begin{array}{c}\text { Astaxanthin } \\
\text { Concentration } \\
\left(\mathrm{mgL}^{-1}\right)\end{array}$ \\
\hline \multirow{2}{*}{$\begin{array}{l}\text { Isolate B1 } \\
\text { (Chlorella sp.) }\end{array}$} & $1 \mathrm{M} \mathrm{NaCl}$ & $18 \times 10^{-2} \pm 0.5 \times 10^{-2}$ & $30.62 \times 10^{-3} \pm 2.1 \times 10^{-3}$ & $4 \times 10^{-5} \pm 0.9 \times 10^{-5}$ \\
\hline & Control & $92 \times 10^{-2} \pm 1.8 \times 10^{-2}$ & $138.41 \times 10^{-3} \pm 4.3 \times 10^{-3}$ & $40 \times 10^{-5} \pm 2.3 \times 10^{-5}$ \\
\hline \multirow{2}{*}{$\begin{array}{c}\text { Isolate B2 } \\
\text { (Picochlorum maculatum) }\end{array}$} & $1 \mathrm{M} \mathrm{NaCl}$ & $12 \times 10^{-2} \pm 1.96 \times 10^{-2}$ & $33.57 \times 10^{-3} \pm 2.03 \times 10^{-3}$ & $2 \times 10^{-5} \pm 0.2 \times 10^{-5}$ \\
\hline & Control & $132 \times 10^{-2} \pm 2.9 \times 10^{-2}$ & $366.3 \times 10^{-3} \pm 4.2 \times 10^{-3}$ & $70 \times 10^{-5} \pm 4.3 \times 10^{-5}$ \\
\hline \multirow{2}{*}{$\begin{array}{l}\text { Isolate B3 } \\
\text { (Chlorella sp.) }\end{array}$} & $1 \mathrm{M} \mathrm{NaCl}$ & $28 \times 10^{-2} \pm 1.2 \times 10^{-2}$ & $27.5 \times 10^{-3} \pm 1.6 \times 10^{-3}$ & $1 \times 10^{-5} \pm 0.1 \times 10^{-5}$ \\
\hline & Control & $85 \times 10^{-2} \pm 1.65 \times 10^{-2}$ & $103.48 \times 10^{-3} \pm 5.2 \times 10^{-3}$ & $20 \times 10^{-5} \pm 1.6 \times 10^{-5}$ \\
\hline \multirow{2}{*}{$\begin{array}{c}\text { Isolate S2 } \\
\text { (Picochlorum maculatum) }\end{array}$} & $1 \mathrm{M} \mathrm{NaCl}$ & $14 \times 10^{-2} \pm 0.4 \times 10^{-2}$ & $14.76 \times 10^{-3} \pm 1.9 \times 10^{-3}$ & $0.6 \times 10^{-5} \pm 0.04 \times 10^{-5}$ \\
\hline & Control & $279 \times 10^{-2} \pm 3.4 \times 10^{-2}$ & $549.5 \times 10^{-3} \pm 6.9 \times 10^{-3}$ & $140 \times 10^{-5} \pm 5.5 \times 10^{-5}$ \\
\hline
\end{tabular}

isolates B1 and B3 are close relationships with a Chlorella sp., while isolates B2 and S2 are close relationships with Picocblorum maculatum (Figure 4).

Based on the growth curve, the time to take the starter culture is determined on the $6^{\text {th }}$ day, which is half the exponential period of culture. Starters are used as seeds for making cultures for the mass production of microalgae (Perumal et al. 2012). While in Figure 4B. shows the OD value of the isolates with $1 \mathrm{M}$ of $\mathrm{NaCl}$ salinity stress is lower than the $\mathrm{OD}$ value of the isolates without salinity stress in Figure 5A. Figure 5B shows that the harvest time and measurement of chlorophyll, carotenoid, and astaxanthin concentrations were carried out in the final exponential phase, namely on $13^{\text {th }}$ day for isolates B1 and B3 and 10th day for isolates B2 and S2.

Table 2 above shows the results of measuring the concentration of chlorophyll, carotenoids, and astaxanthin in the four microalgae isolates under $1 \mathrm{M} \mathrm{NaCl}$ stress.

\section{Discussion}

The electrophoresis results in Figure 3A show that the microalgae DNA samples of isolates B1, B2, B3, and S2 can be amplified with the primer pairs that have been designed. The size of the DNA amplification results of each isolate was in the fragment size range between $1000 \mathrm{bp}$ to $1500 \mathrm{bp}$. This is in accordance with the research of Rismiarti et al. (2016), who received electrophoretic fragments at $\pm 1250 \mathrm{bp}$ in the analysis of the microalgae Cblorella vulgaris using the $18 \mathrm{~S}$ rRNA marker gene. Good amplification results are indicated by a thick DNA band and there is little or no smear on the gel when visualized in ultraviolet light (Safitri et al. 2018) Phylogenetic tree construction was carried out to determine the groups and species relationships. The phylogenetic tree was designed using microalgae 18SrRNA sequences from GenBank as BLASTn results, which showed that isolates B1, B2, B3, and S2 belonged to this group of sequences (in group). The phylogenetic tree shows that both isolates B1 and B3 have a very close relationship with Chlorella sp. while isolates B2 and S2 have a close relationship with Picocblorum maculatum. The genus Chlorella and the genus Picochlorum belong to the division Chlorophyta. The genus Chlorella has approximately 13 members of the species with a single green cell, spherical in shape with a diameter of 2 to $10 \mathrm{~m}$, not flagellated. The chloroplasts contain the photosynthetic pigments chlorophyll $\mathrm{a}$ and $\mathrm{b}$. In an optimal environment for growth, Chlorella will divide rapidly by requiring only carbon dioxide, 
sunlight, water, and minerals (Scheffler 2007). According to Henley et al. (2004) members of the genus, Picochlorum is a species of small unicellular microalgae measuring 1-3 m, oval in shape, having chlorophyll pigment which is surrounded by a cell wall. Members of this genus are isolated from marine and estuary ecosystems with different salinity levels.

Based on the growth curve in Figure 5A, the time to take the starter culture is determined on the $6^{\text {th }}$ day, which is half the exponential period of culture, because during the exponential period the cells are still actively dividing and can carry out metabolism maximally before entering the stationary phase or cell death (Agustini 2012; Widayat 2015). Starters are used as seeds for making cultures for the mass production of microalgae (Perumal et al. 2012). Figure 5B shows the OD value of the isolates with $1 \mathrm{M}$ of $\mathrm{NaCl}$ salinity stress is lower than the OD value of the isolates without salinity stress in Figure 5A. Giving $1 \mathrm{M}$ of $\mathrm{NaCl}$ causes the final exponential phase shift to enter the stationary phase faster, which means that microalgae cultures enter the death phase faster. According to Erlina (2007), changing salt levels in water can cause growth barriers for culture. High salinity will result in $\mathrm{Na}^{+}$ poisoning. Excessive $\mathrm{Na}^{+}$ions can inhibit $\mathrm{K}^{+}$uptake from the environment, where $\mathrm{K}^{+}$ions play a role in maintaining cell turgor and enzyme activity. Salinity stress also inhibits the absorption of water and elements through the osmosis process. The amount of water that enters the cell is reduced because the pressure outside the cell is higher than the pressure inside the cell, this situation makes the cell respond by attracting ions. But at the same time, water withdrawal from the vacuole continues which results in a reduced amount of water supply in the cell and results in cell shrinkage (Arisandi et al. 2011).

In this study, harvest time and measurement of chlorophyll, carotenoid, and astaxanthin concentrations were carried out in the final exponential phase, namely on $13^{\text {th }}$ day for isolates B1 and B3 and $10^{\text {th }}$ day for isolates B2 and S2. At the end of the exponential phase, microalgae experience the highest growth peak and cell density so that the biomass content in the cells will be higher (Isnansetyo \& Kurniastuti 1995; Duong et al. 2012).

From Table 2, it can be seen that in all isolate cultures the concentration of all pigments decreased in the $1 \mathrm{M} \mathrm{NaCl}$ salinity treatment when compared to the control treatment. This study used salinity stress of 1 $\mathrm{M} \mathrm{NaCl}$ or equal to $83 \% 0 \mathrm{NaCl}$ and the treatment without salinity stress (control) was equal to $35 \% \mathrm{NaCl}$. The optimum salinity value for producing chlorophyll in microalgae is $20 \%$ (Shang et al. 2018) with the ability of photosynthesis which can still take place at a salinity of $30 \%$ to produce a fairly high cell density (Sedjati et al. 2019). So based on this, it can be said that the $1 \mathrm{M} \mathrm{NaCl}$ treatment given is too high for microalgae to perform photosynthesis well. Too much $\mathrm{NaCl}$ treatment can be toxic and result in very disturbed cell metabolism.

The decrease in photosynthesis due to high salinity treatment will result in a decrease in cell density. Photosynthesis is an important process that supports plant growth and its efficiency is a factor that determines the level of plant resistance to abiotic stress. The efficiency of photosynthesis is determined, among others, by photosystems, photosynthetic pigments, electron transport systems, gas exchange processes, and enzymes that participate in carbon metabolism (Tsai et al. 2019). Research on rice species that are sensitive to salinity showed that the salinity treatment resulted in the chlorophyll fluorescence parameter decreased significantly when compared to salinity tolerant species. When a large number of $\mathrm{NaCl}$ molecules enter plant cells, the chloroplast and thylakoid membrane systems are damaged and affect the photosynthesis process if the salt concentration cannot be 
regulated to an optimal value (Tsai et al. 2019). In Caryophyllaceae plants that experienced a $\mathrm{NaCl}$ stress of $0.6 \%$ and $0.9 \%$, there was a disturbance in chloroplast development (Ma et al. 2017). The salinity in this study was very high, so it is likely to cause damage to photosynthetic pigments and cause the concentration value to decrease significantly when compared to the treatment without salinity stress (control).

Pelah et al. (2004) stated that giving salinity stress can increase carotenoid production which will also increase the number of secondary carotenoid levels, especially astaxanthin. Astaxanthin is an antioxidant that is produced as a defense mechanism to survive from the presence of Reactive Oxygen Species (ROS). Salinity stress increases the production of ROS which can lead to metabolic disorders and cell damage (Moller et al. 2007; Jaleel et al. 2009; Miller et al. 2010; Habib et al. 2016; Hossain \& Karl 2016). Excessive accumulation of ROS will react with suitable targets such as nucleic acids, proteins, lipids, and chlorophyll. ROS is a highly reactive form of molecular oxygen, including hydroxyl radicals $(\mathrm{HO})$, superoxide $\left(\mathrm{O}_{2}{ }^{-}\right)$ hydrogen peroxide $\left(\mathrm{H}_{2} \mathrm{O}_{2}\right.$ ), and singlet oxygen $\left({ }^{1} \mathrm{O}_{2}\right)$ (Dowling \& Simmons 2009; Shapiguzov et al. 2012; Saha et al. 2015). During stress, the production of ROS will increase due to differences in membrane fluidity which can hinder the transfer of electrons to photosystem II (PS II) (Chaves et al. 2009; Biswal et al. 2011; Silva et al. 2011; Jajoo 2013; Saha et al. 2015). Excess production of ROS when stress occurs in plants must be overcome by plants by producing antioxidants. Research by Ma et al. (2017) shows that salicylic acid as one of the growth regulators in plants has the effect of relieving poor growth and physiological conditions when plants experience salinity stress, namely by improving growth, increasing the activity of antioxidant synthesis enzymes, improving the development of stomata and chloroplasts. In Table 2 , the carotenoid and astaxanthin concentrations did not increase in the $1 \mathrm{M}$ $\mathrm{NaCl}$ salinity treatment. This may occur because the concentration of $\mathrm{NaCl}$ given is very high which results in distuption of the synthesis machinery of growth regulators such as salicylic acid so that it is unable to increase the activity of the enzyme synthesis of antioxidant pigments including carotenoids and astaxanthin. Thus, data collection on the concentration of chlorophyll, carotenoids, and astaxanthin in this study could not be used to describe the mechanism of carotenogenesis in microalgae cells subjected to $\mathrm{NaCl}$ concentration of $1 \mathrm{M}$. However, the results of this study showed that all isolates were able to synthesize astaxanthin even in small amounts and could be increased by salinity treatment at concentrations lower than $1 \mathrm{M}$ or by other stress treatments. This research has supported the exploration of Indonesia's local natural resources that have the potential to produce astaxanthin.

\section{CONCLUSION}

Exploration of the diversity of microalgae obtained from mangrove waters in the area of Sepulu Bangkalan Madura and northern coastal waters of Sowan Tuban succeeded in isolating four microalgae isolates and identified molecularly with the $18 \mathrm{~S}$ rRNA gene marker. Isolates B1 and B3 were close to Chlorella vulgaris, isolate $\mathrm{B} 2 \mathrm{had}$ a close relationship with Prasinoderma coloniale, and isolate S2 had a close relationship with Picochlorum oklahomense. Giving salinity of $1 \mathrm{M} \mathrm{NaCl}$ had a bad effect, namely decreased growth and decreased levels of chlorophyll, carotenoids, and astaxanthin pigments in the culture of all microalgae isolates.

\section{AUTHORS CONTRIBUTION}

D.E. as a main and correspondence author designed the research, analyzed the data, and wrote the manuscript, S.Y.R, T.M., L.P.D.C.B collected the 
data, T.B.S. analyzed the phylogenetic tree, H.P. and $\mathrm{N}$ are the promoter and co-promoter respectively in this research and both conduct supervised all the processes

\section{ACKNOWLEDGMENTS}

We would like to express our deepest appreciation to all research teams for their solid cooperation during the research. We are also very grateful to the Ministry of Research Technology and Higher Education of the Republic of Indonesia which has funded this research in the Postgraduate Doctoral Dissertation Research scheme with Agreement Number 4/AMD/E1/ KP.PTNBH/2020 and research contract number 801/UN3.14/PT/ 2020.

\section{CONFLICT OF INTEREST}

There is no conflict of interest in the research that has been carried out and the publication of this article.

\section{REFERENCES}

Arisandi, A. et al., 2011. Pengaruh Salnitas Yang Berbeda Terhadap Morfologi, Ukuran dan Jumlah Sel, Pertumbuhan serta Rendemen Keraginan Kappaphycus alvarezii. Jurnal Ilmu Kelautan, 16(3), pp.143-150.

Agustini, N.W.S., A friastini, M. \& Maulida, Y., 2012. Potential of Fatty Acid from Microalgae Nannochloropsis sp. as Antioxidant and Antibacterial; Proceeding of Seminar Nasional XI Pendidikan Biologi FKIP. Universitas Sebelas Maret Surakarta, Surakarta.

Azzahidah, A. \& Ermavitalini, D., 2016. Isolasi, Karakterisasi dan Seleksi Mikroalga yang Berpotensi sebagai Bahan Baku Biodiesel dari Perairan Wonorejo Selatan, Proceeding of Seminar Nasional Biodiversitas VI, Airlangga University.

Biswal, B. et al., 2011. Photosynthesis, a global sensor of environmental stress in green plants: stress signalling and adaptation. Curr.Sci, 101, pp.47-56.

Chaves, M.M., Flaxes, J. \& Pinheiro, C., 2009. Photosynthesis under drought and salt stress regulation mechanism from whole plant to cell. Annals of Botany, 103(4), pp.551-556.

Chen, J., Wei, D. \& Pohnert, G., 2017. Rapid Estimation of Astaxanthin and the Carotenoid-to-Chlorophyll Ratio in the Green Microalga Chromochloris zofingiensis Using Flow Cytometry. Marine Drugs, 15(7), 231.

Coates, C.R., Trentacoste, E. \& Gerwick, W.H., 2013, 'Bioactive and novel chemicals from microalgae', in A. Richmond A, Hu Q (eds.), Handbook of microalgal culture, John Wiley \& Sons, New York.

Collins, A.M. et al., 2011. Carotenoid Distribution in Living Cells of Haematococcus pluvialis (Chlorophyceae). PLoS One, 6(9), e24302.

Demmig-Adams, B., Gilmore, A.M. \& Adams, W.W., 1996. Carotenoids 3: In vivo function of carotenoids in higher plants. FASEB Journal, 10(4), pp.403-412.

Dowling, D.K. \& Simmons, L.W., 2009. Reactive oxygen species as universal constraint in life-history evolution. Proc. R. Soc. B., 276(1663). pp.17371745.

Duong, V.T.Y. et al., 2012. Microalgae Isolation and Selection for Prospective Biodiesel Production. Energies, 5, pp.1835-1849.

Elfiza, W.N., Abdi, D. \& Nasril, N., 2019. Penapisan mikroalga penghasil karotenoid serta studi pengaruh stress nitrogen dan fosfor terhadap produksi Beta karoten pada mikroalga Oocystis sp. JPB Kelautan dan Perikanan, 14(1), pp.9-20. 
Endrawati, H. \& Riniatsih, I., 2013. Kadar Total Lipid Mikroalga

Nannochloropsis oculate yang Dikultur Dengan Suhu yang Berbeda. Buletin Oseanografi Marina, 1, pp.25-33.

Erlina, A., 2007. Produksi Pakan Hidup; Materi Pelatihan Pembenihan Udang. Laboratorium Pakan Alami Balai Besar Pengembangan Budidaya Air Payau Jepara, Jepara.

Guerin, M., Huntley, M.E. \& Olaizola, M., 2003. Haematococcus astaxanthin: applications for human health and nutrition. Trends Biotechnol, 21, pp. 210-216.

Guiry, M.D., 2012. How Many Species of Algae Are There? Journal of Phycology, 48, pp.1057-1063.

Habib, S.H., Kausar, H. \& Saud, H.M., 2016 .Plant growth- promoting Rhizobacteria enhance salinity stress tolerance in Okra through ROSscavenging enzymes. Biomed.Res.Int., 2016, 6284547.

Hajibabaei, M. et al., 2007. DNA barcoding: how it complements taxonomy, molecular phylogenetics and population genetics. Trends Genet, 1(1), pp. 1-6.

Han, D., Yantao, L. \& Qtang, H., 2013. Astaxanthin in microalgae: pathways, functions and biotechnological implications. Algae, 28(2), pp.131-147.

Hebert, P.D.N. et al., 2003. Biological identifications through DNA barcodes. Proc. R. Soc. B., 270, pp.313-321.

Henley, W.J. et al., 2004. Phylogenetic analysis of the 'Nannochloris-like'algae and diagnoses of Picochlorum oklahomensis gen. et sp. nov.

(Trebouxiophyceae, Chlorophyta). Phycologia, 43(6), pp.641-652

Henriquez, M., Silva, A. \& Rocha, J., 2007. Extraction and Quantification of Pigments from a Marine Microalga: A Simple and Reproducible Method. FORMATEX, 1, pp.586-593.

Hossain, M.S. \& Karl, J.D., 2016. Turning of Redox Regulatory Mechanisms, Reactive Oxygen Species and Redox Homeostasis under salinit stress. Frontiers in plant science, 7, 548.

Isnansetyo, A. \& Kurniastuty, 1995, Teknik Kultur Pytoplankton dan Zooplankton Pakan Alami untuk Pembenihan Organisme Laut, Kanisius, Yogyakarta.

Jajoo, A., 2013. 'Changes in photosystem II in response to salt stress' in P. Ahmad, M.M. Azooz, M.N.V. Prasad (eds), Ecophysiology and Responses of Plants under Salt Stress, Springer. New York.

Jaleel, C.A. et al., 2009. Antioxidant defense responses: physiological plasticity in higher plants under abiotic constraints. ActaPhysiol.Planta., 31, pp.427-436.

Lasabuda, R., 2013. Pembangunan Wilayah Pesisir dan Lautan Dalam Perspektif Negara Kepulauan Republik Indonesia. Jurnal Ilmiah Platax, 1(2), pp.92-101.

Leya, T. et al., 2009. Response of arctic snow and permafrost algae to high light and nitrogen stress by changes in pigment composition and applied aspects for biotechnology. FEMS Microbiol. Ecol, 67, pp.432443.

Li, F. et al., 2019. Differences between Motile and Nonmotile celss of Haematococcus pluvialis In the production of Astaxanthin at different light Intensities. Marine drugs, 17(39).

Lichtenthaler, H.K., 1987. Chlorophylls and Carotenoids: Pigments of Photosynthetic Biomembranes. Methods in Enzymology, 148, pp. 350382.

Lorenz, R.T. \& Cysewski, G.R., 2000. Commercial potential for Haematococcus microalgae as a natural source of astaxanthin. Trends Biotechnol, 18(4), pp.160-167. 
Ma, R.Y.N. \& Chen, F., 2001. Enhanced production of free trans-astaxanthin by oxidative stress in the cultures of the green microalga Chlorococcum sp. Process Biochem, 36, pp.1175-1179.

Ma, X. et al., 2017. Salicylic Acid Alleviates the Adverse Effects of Salt Stress on Dianthus superbus (Caryophyllaceae) by Activating Photosynthesis, Protecting Morphological Structure, and Enhancing the Antioxidant System. Frontiers in Plant Science, 8, 600.

Miller, G. et al., 2010. Reactive oxygen species homeostasis and signalling during drought and salinity stresses. Plant Cell Environ, 33(4), pp.453467.

Moller, I.M., Jensen, P.E. \& Hansson, A., 2007. Oxidative modifications to cellular components in plants. Annu. Rev. Plant Biol., 58. pp.459-481.

Mulders, K.J.M. et al., 2015. Nitrogen-depleted Chlorella rofingiensis produces astaxanthin, ketolutein and their fatty acid esters: A carotenoid metabolism study. J. Appl. Phycol., 27, pp.125-140.

Mustafa, H., Rachmawati, I. \& Udin, Y., 2016. Pengukuran Konsentrasi dan Kemurnian DNA Genom Nyamuk. Jurnal Vektor Penyakit, 10(1), pp.710.

Noor, Y.R., Khazali, M. \& Suryadiputra, I.N.N., 1999. Panduan Pengenalan Mangrove di Indonesia. PHKA/WI-IP, Bogor.

Orosa, M. et al., 2000. Production and analysis of secondary carotenoids in green algae. J. Appl. Phycol, 12(3), pp.553-556.

Pelah, D., Amnon, S. \& Ephrain, C., 2004. The effect of salt stress on the production of canthaxanthin and astaxanthin by Chlorella zofingiensis grown under limited light intensity. World Journal of Microbiology \& Biotechnology, 20, pp.483-486.

Perumal, P. et al., 2012. Isolation and Culture of Microalgae; Workshop on Advances in Aquaculture Technology. Bharathidasan University, Tamil Nadu.

Pratama, A.J. \& Laily, A.N., 2015. Analisis Kandungan Klorofil Gandasuli (Hedychium garderianum Shephard ex Ker-Gawl) pada Tiga Daerah Perkembangan Daun yang Berbeda; Proceeding of Seminar Nasional Konservasi dan Pemanfaatan Sumber Daya Alam. Sebelas Maret University, Surakarta.

Qin, S., Liu, G.X. \& Hu, Z.Y., 2008. The accumulation and metabolism of astaxanthin in Scenedesmus obliquus (Chlorophyceae). Process Biochem, 43, pp.795-802.

Remias, D. et al., 2010. Physiological and morphological processes in the alpine snow alga Chloromonas nivalis (Chlorophyceae) during cyst formation. Protoplasma, 243, pp.73-86.

Rismiarti, A., Kusumaningrum, H.P. \& Zainuri, M., 2016. Karakterisasi Dan Identifikasi Molekuler Fusan Hasil Fusi Protoplas Interspesies Chlorella pyrenoidosa dan Chlorella vulgaris Menggunakan 18SrDNA. Jurnal Bioma: Berkala Ilmiah Biologi, 18(2), pp.30-40.

Safitri, R., 2018, 'Isolasi Bakteri Penghasil Anzim Protease Bacillus thuringiensis IRODI pada Oncom Merah Pasca Fermentasi 24 Jam', Proceeding of Seminar Nasional Edusaintek, Universitas Muhammadiyah Semarang, Semarang.

Saha, J., 2015. Polyamines as redox homeostasis regulators during salt stress in plants. Frontiers in Environmental Science, 3, 21.

Sambrook, J., Fritsch, E.F. \& Maniatis, T., 1989, Molecular Cloning: A Laboratory Manual. 2nd ed, Cold Spring Harbor Laboratory Press, New York.

Saputro, T.B. et al., 2019. Isolation of high lipid content microalgae from Wonorejo river, Surabaya, Indonesia and its identification using rbcL marker gene. Biodiversitas, 20(5), pp.1380-1388. 
Scheffler, J., 2007. Underwater Habitats. Illumin, 9(4).

Sedjati, S. et al., 2019. Chlorophyll and Carotenoid Content of Dunaliella salina at Various Salinity Stress and Harvesting Time. Proceeding of 4th International Conference on Tropical and Coastal Region Eco Development, IOP Conf. Ser.: Earth Environ. Sci., 246, 012025.

Shang, C. et al., 2018. The Responses of Two Genes Encoding Phytoene Synthase (Psy) and Phytoene Desaturase (Pds) to Nitrogen Limitation and Salinity up-Shock with Special Emphasis on Carotenogenesis in Dunaliella parva. Algal Research Journal, 32, pp.1-10.

Shapiguzov, A., 2012. ROS talk how the apoplast, the chloroplast, and the nucleus get the message through. Frontiers in Plant Science, Vol 27(3), 292.

Silva, E.N., 2011. Salt stress induced damages on the photosynthesis of physic nut young plants. Scientia Agricola (Piracicaba Bra\%), 68(1), pp.6268.

Sulardiono, B., Hutabarat \& Djunaedi, A., 2015. Buku Ajar Planktonologi. Universitas Diponegoro, Semarang.

Suparman, 2012. Marka molekuler dalam identifikasi dan analisis kekerabatan tumbuhan serta implikasinya bagi mata kuliah genetika. Jurnal bioedukasi, $1(1)$.

Thao, T.Y. et al., 2017. Isolation and Selection of Microalgal Strains from Natural Water Sources in Viet Nam with Potential for Edible Oil Production. Marine Drugs, 15, p.194

Tsai, Y.C. et al., 2019. Chlorophyll fluorescence analysis in diverse rice varieties reveals the positive correlation between the seedlings salt tolerance and photosynthetic efficiency. BMC Plant Biology, 19, 403.

Wang, N. et al., 2018. Identification of Salt Stress Responding Genes Using Transcriptome Analysis in Green Alga Chlamydomonas reinhardtii. International Journal of Molecular Sciences, 19(11), 3359.

Widayat \& Hadiyanto, 2015. Pemanfaatan Limbah Cair Industri Tahu Untuk Produksi Biomassa Mikroalga Nannochloropsis sp. Sebagai Bahan Baku Biodiesel. Jurnal Reaktor, 15(4), pp.253-260.

Yanuhar, U., 2016, Mikroalga Laut Nannochloropsis oculate, UB Press, Malang.

Zawislak, G. \& Renata, N.W., 2014. Evaluation of the yield and biological value of tarragon (Artemisia dracunculus L.) in the bunch harvest cultivation. Acta Sci. Pol., Hortorum Cultus, 13(4), pp.185-198.

Zulfahmi, 2013. Penanda DNA untuk analisis genetik tanaman. Jurnal Agroteknologi, 3(2). 